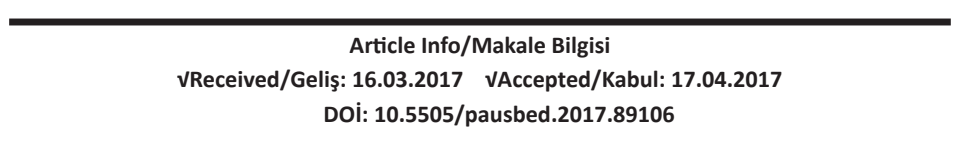

\title{
PSYCHOMETRIC STUDY OF THE TURKISH SURVEY OF PERCEIVED ORGANIZATIONAL SUPPORT (SPOS)
}

\author{
Özlü DOLMA*,Ayşe Alev TORUN**
}

\begin{abstract}
In this study, the psychometric properties of the "Survey of Perceived Organizational Support" (SPOS) developed by Eisenberger et al. (1986) are investigated to provide further empirical evidence on its reliability and validity. In Study I, the effects of using different number of response options (5-point vs. 6-point Likert scales) and different anchoring labels (fully-labeled vs. end-anchored response scale) on participants' responses to SPOS items are investigated. Results showed that the anchoring labels and the number of response categories did not have a dramatic impact on the participants' responses to SPOS items. Alpha coefficients were very high for all of the four different scale designs of SPOS, but the fully-labeled, 6-point Likert scale had the highest reliability coefficient. Exploratory factor analyses (EFA) findings provided support for the unidimensionality of SPOS. In Study II, the test-retest reliability of the 16-item version of SPOS was examined. Results provided evidence of high test-retest reliability.

Keywords: Survey of Perceived Organizational Support, Psychometric Evaluation, Reliability, Validity, Scale Design, Number of Response Categories, Likert-type Rating Scales
\end{abstract}

\section{ALGILANAN KURUMSAL DESTEK ÖLÇEĞININ PSIKOMETRIK AÇIDAN INCELENMESi}

\section{Özet}

Bu araştırmada Eisenberger ve diğerleri (1986) tarafından geliştirilmiş olan “Algılanan Kurumsal Destek Ölçeği”nin Türkçe formu geliştirilmiş ve psikometrik özellikleri detaylı olarak incelenmiştir. Araştırma birbirini takip eden iki ayrı çalışmadan oluşmaktadır. İlk çalışmada, 5'li ve $6^{\prime}$ lı Likert ölçeği kullanımının ve bu ölçekleri etiketlendirmenin etkileri araştırılmıştır. Bu bağlamda 4 farklı ölçek tipine sahip (5'li ya da $6^{\prime}$ lı Likert ile tüm seçenekler etiketlenmiş ya da sadece ilk ve son seçenek etiketlenmiş) anket formları geçerlilik ve güvenilirlikleri bakımından karşılaştırılmıştır. Tüm seçeneklerin etiketli olduğu 6'lı Likert ölçeğinin diğerlerine göre daha yüksek güvenilirlik katsayısına sahip olduğu saptanmıştır. Keşfedici Faktör Analizi ("Temel Eksen Faktör Analizi” ile) sonuçları ölçeğin tek boyutlu yapısını desteklemiştir. İkinci çalışmada tüm seçeneklerin etiketlenmiş olduğu 6’lı Likert ölçeği kullanılarak "Algılanan Kurumsal Destek Ölçeği”nin kısa formunun psikometrik özellikleri incelenmiştir. Bu amaçla ölçek, testyeniden test güvenilirlik analizine tabi tutulmuştur. Yüksek test-yeniden test güvenirlik katsayısı elde edilmiştir. Anahtar Kelimeler: Algılanan Kurumsal Destek Ölçeği, Psikometri, Geçerlilik, Güvenilirlik, Likert Ölçeği, Ölçek Tasarımı.

*Phd.D., Department of Organizational Behavior,DENIZLI.

e-mail: ozludolma@gmail.com

**Ph.D., Marmara University, Faculty of Business Administration, Department of Organizational Behavior, ISTANBUL.

e-mail:atorun@marmara.edu.tr

This paper is based on a portion of the first author's doctoral dissertation, which was completed under the supervision of the second author. I would like to express my appreciation to my former supervisor, Güler İslamoğlu, and the dissertation committee members, Cavide Uyargil, Serra Yurtkoru, Tülay Turgut, and Serkan Dolma, for their invaluable comments and advice. 


\section{INTRODUCTION}

Perceived Organizational Support (POS) is defined as employees' perception concerning the extent to which the organization values their contribution and cares about their well-being (Eisenberger et al., 1986: 501). Since its emergence, POS has received increasing attention by scholars and practitioners and the research on Organizational Support Theory (OST) has burgeoned over the past three decades. A review of the Social Science Citation Index (SSCl) for the literature from 1986 to 2016 (using Cited Reference Searching accessed via Web of Science) revealed that Eisenberger, et al.'s (1986) article "Perceived Organizational Support" alone has been cited 1705 times.

Organizational support theory supposes that employees form a general perception regarding the extent to which the organization appreciates their contributions and is concerned with their well-being. That is, employees make inferences concerning the organization's commitment to them (Eisenberger et al., 1986: 504) and form global beliefs about their valuation by the organization. These perceptions of organizational support enable employees to determine whether the organization is ready to reward their increased efforts made on its behalf and to meet their socioemotional needs (Eisenberger et al., 1986: 501; Rhoades and Eisenberger, 2002: 698). According to organizational support theory, being valued by the organization is seen by employees as an assurance that they will receive benefits such as approval and respect, pay and promotion, access to information, and other forms of aid needed to carry out one's job effectively, in return for their behaviors that benefit the organization and for their positive attitudes towards the organization (Rhoades and Eisenberger, 2002: 698).

Organizational support theory led the employers to realize that employees form a general perception regarding organization's commitment to them and introduced a new perspective to researchers for understanding the relationship between the employee and the organization. Meta-analytic findings provided support that POS is statistically and significantly associated with important outcomes for employees such as job satisfaction, organizational commitment, employee performance, and intention to leave (Riggle et al., 2009: 1027). A more recent metaanalytic evaluation of OST by Kurtessis et al. (2015:1) revealed that POS has a crucial role as a link between favorable treatment by the organization in terms of leadership, fairness, human resource practices, and working conditions, and positive attitudinal and behavioral outcomes such as trust in the organization, organizational identification, affective commitment, and reduced job stress, burnout, withdrawal behaviors.

\section{THE SURVEY OF PERCEIVED ORGANIZATIONAL SUPPORT (SPOS)}

To operationalize Perceived Organizational Support, Eisenberger et al. (1986: 502) constructed statements measuring the evaluative judgments attributed to the organization by employees, and employees' beliefs regarding the discretionary actions affecting them that the organization would be likely to take in diverse hypothetical situations (Eisenberger et al., 1986: 501). The scale comprising these statements has been termed the "Survey of Perceived of Organizational Support" (SPOS) and conceptualized as a unidimensional construct.

In the original scale development study of SPOS (Eisenberger et al., 1986: 502), the scale consisted of 36 items. In order to control for the possible effects of agreement or disagreement response biases, approximately half of the items were worded in the positive direction, and the remaining items were worded in the negative direction. Items were presented in a random order. Responses of employees to SPOS were obtained by using a 7-point Likert-type scale with response options: 1 = "strongly disagree", 2 = "moderately disagree", 3 = "slightly disagree", 4 = "neither agree nor disagree", 5 = "slightly agree", $6=$ "moderately agree" and 7 = "strongly agree". The sample consisted of 361 employees from 9 different organizations.

Initial evidence for the reliability of SPOS was promising. Eisenberger et al.'s (1986: 503) reliability analysis of 36-item and 17-item SPOS resulted in alpha coefficients of .97 and .93, 
respectively. For the 36 -item SPOS, item-total correlations ranged from .42 to .83 . Since the original SPOS is conceptually unidimensional and has high internal reliability, the use of shorter versions of the scale, especially the 17-item version, has been recommended by Eisenberger and his colleagues (1986: 503; Rhoades and Eisenberger, 2002: 699). Accordingly, all of the studies that examined the underlying structure of SPOS to establish its dimensionality used (probably, for practical reasons) a reduced number of SPOS items (e.g. 17-items, 8-items, and 3-items).

\section{PURPOSE OF THE STUDY}

The present study was undertaken in response to a gap in the Turkish literature on the reliability and construct validity evaluation of the SPOS. To our knowledge, no systematic empirical research has been conducted investigating the psychometric properties of the Turkish version of the SPOS. Several Turkish researchers examined the antecedents and behavioral outcomes of POS, but did not provide comprehensive evidence on the reliability and validity of the scale. Due to lack of research establishing the psychometric properties of the Turkish version of the scale, the use of it in Turkish samples becomes questionable.

One purpose of this study is to examine the appropriate number of categories for Likerttype items and the effects of using different verbal labels to anchor the scale points. Likerttype scale (1932: 17) is one of the most, if not the most, commonly used type of attitude and psychological construct measurement instrument in social and behavioral science research. Instruments with Likert-type scales present respondents with statements to which they indicate their extent of agreement based on a continuum typically ranging between the extremes, such as disagree-agree (Adelson and McCoach, 2010: 797). Many researchers have attempted to examine the most appropriate number of response categories in terms of reliability and validity (Chang, 1994: 206; Colman et al., 1997: 355) but the findings from these studies were contradictory (Chang, 1994, p.206; Wakita et al., 2012: 534). Some of these studies indicated that the number of response categories has no effect on coefficient alpha at all, whereas in other studies, researchers reported an effect but recommended different number of response options (particularly, 3-, 4-, 5-, and 7-point scales) as the optimum number of response categories (Adelson and McCoach, 2010: 797; Chang, 1994: 206). In fact, it is argued that when respondents are presented with a scale that has too many response categories and requires a finer discrimination, it adds measurement error to their total scores since they cannot distinguish easily between the adjacent categories. On the other hand, with too few response categories, the scale may not elicit adequate level of information on individual differences and would have less variability (Adelson and McCoach, 2010: 799; Matell and Jacoby, 1971: 657).

Other than the problem of determining the optimum number of response categories, the issue of whether an even or odd number of categories should be offered has also been debated but the conclusions drawn from the studies were indeterminate as well (Adelson and McCoach, 2010: 797; Chang, 1997: 802; Chang, 1994: 206). An odd number of categories provides respondents with a neutral anchor such as "neither agree nor disagree" which allows respondents to indicate a neutral response whereas an even number of categories forces respondents to indicate their attitudes in terms "agreement" or "disagreement" (Colman et al., 1997: 356; Wakita et al., 2012: 534). Some researchers have expressed concern that when a middle category is presented to the respondents, they will be less discriminating and declare themselves neutral more often, whereas omitting the neutral point will force respondents to be more thoughtful which would result in a more precise measurement (Adelson and McCoach, 2010: 797).

Apart from the contradictory findings in relation to the appropriate number of categories for Likert scales, researchers have also examined the effects of using different anchoring 
labels associated with Likert-type scale points. Most of the existing studies compared scales that were fully labeled, labeled at two ends, and not labeled. The findings of these studies have been mixed (Chang, 1997: 801).

These controversies were one of the primary motivators for us to conduct a study on the effects of scale design. Accordingly, we also tried to find an answer whether there is an optimal number of response options for SPOS by investigating the effects of using different number of categories (5-point and 6-point Likert-type scales) and different anchoring labels (fully-labeled response scale and end-anchored response scale) on items' performance in measuring the participants' true scores and in discriminating among participants with varying levels of the construct being measured. In the majority of the previous studies, researchers investigated the optimal number of response options from the perspective of internal consistency reliability (e.g. Adelson and McCoach, 2010: 798; Matell and Jacoby, 1971: 659; Wakita et al., 2012: 534). In this study, however, besides the internal consistency reliability findings, validity evidence based on exploratory factor analyses is provided for the four different scale designs of the SPOS.

Based on the results of the first study and following Eisenberger et al.'s (1986: 502) recommendation, a second study was conducted to examine the test-retest reliability of the 16-item version of SPOS (17-item version of SPOS that Eisenberger et al. (1986: 502) recommended as a shorter version of the scale but excluding Item 2 in the original study). To the best of authors' knowledge, previously, no study has examined the test-retest reliability of the SPOS. This might be due to the necessity and the difficulty of repeatedly administering the same scale to the same individuals. Researchers almost always prefer estimating coefficient alpha to assess the reliability of a scale since it requires only a single administration of an instrument. In our research context, the assessment of test-retest reliability besides internal consistency reliability has been deemed essential since it provides substantial evidence on reliability by assessing the temporal stability of scores from one administration to another.

\section{STUDY I}

Study I involves; (1) item analyses of SPOS (item difficulty [attractiveness] and item discrimination analyses within the classical test theory framework), (2) an investigation of the effects of using different numbers of response options (5-point and 6-point Likert scales) and different anchoring labels (fully-labeled response scale and end-anchored response scale), (3) the estimation of internal consistency reliabilities of the four versions of SPOS which differ in terms of their scale designs, and (4) the examination of the validity of each version of SPOS by conducting a series of exploratory factor analyses using principal axis factoring (PAF).

\subsection{Participants}

The sample consisted of faculty members including professors, lecturers, teaching and research assistants and instructors, and administrative staff of state and private universities ${ }^{1}$ located in two different cities (Istanbul and Gaziantep) in Turkey. 287 subjects responded to only one of the four different versions of SPOS which were distributed randomly. Other than few exceptions, surveys were collected from the participants the same day that they were distributed. The entire data collection was completed within a two-month period.

Surveys obtained from 11 participants were discarded from the study. These include either incomplete surveys with 4 or more item nonresponse or surveys in which participants predominantly selected middle or another specific category. Such a type of responding clearly indicated that they had not exerted the necessary effort for reading and comprehending the items ${ }^{2}$. Of the remaining surveys 25 included missing data. They were examined to determine 1. Although in daily language they are called private universities, the technically and legally correct term for these type of schools is foundation universities.

2.In survey methodology, this is called satisficing. 
whether there were purposeful patterns of nonresponse. This examination revealed that these surveys had missing values at random. In addition, numbers of surveys which contain missing data were approximately equally distributed among the four survey versions. Subject mean substitution was the method used for handling these missing data. That is, the missing observations of participants were replaced with the mean of their non-missing responses ${ }^{3}$. Reverse items were recoded so that a high score would indicate higher degree of perceived organizational support.

\subsection{Instrument}

8 items of the original SPOS (Eisenberger et al., 1986: 502) were not included in this study for the following reasons: Items 2, 12, 14, 19, and 34 are about employee lay-off and replacement. These items become meaningless when they are administered to a sample which consists of faculty members and administrative staff of state and private universities. Since in Turkey, at state universities, all employees are public servants and have high job security, it is very rare that a faculty member or an administrative staff is laid off because of the reasons mentioned in these items. Similarly, at private universities, employees sign fixed term contracts which obliges the employer to pay high amounts of compensation to employees if the organization terminates the contract before the due date. Items 28,30 , and 32 are about the profitability of the organization and changes in salary. Since at state universities, salary levels are not determined by the organization itself but by the government, these items become meaningless when they are administered to the sample of this study. Moreover, at private universities, employees sign contracts where the salary level has in advance been determined. Therefore, the above mentioned items were excluded from the survey administered in this study. Of 28 items, 11 were reverse-worded items and the remaining 17 were straightforwardly-worded items ${ }^{4}$.

The conceptual equivalents of words and phrases were used to translate the items of SPOS into Turkish. Instead of a word-for-word or a literal translation, a more relaxed style of translation is invoked without changing the essence of the items.

SPOS was formatted in four different ways. For these four different forms of SPOS, all the items had the same phrasing and were presented in the same order. Only, the number of points of Likert-type options (5-point vs. 6-point Likert scales) and labeling anchors (fullylabeled response scale vs. end-anchored response scale) varied which resulted in $(2 \times 2) 4$ different versions. Response scales and scale labels used for these four different forms of SPOS are presented in Table 1 below.

Table 1: Four Different Scale Designs of SPOS

\begin{tabular}{|c|c|c|c|c|c|}
\hline Response & \multicolumn{5}{|c|}{ Category Labels } \\
\hline \multirow{2}{*}{$\begin{array}{l}\text { Fully-labeled } \\
\text { 5-point Likert }\end{array}$} & $\begin{array}{c}\text { Completely } \\
\text { disagree }\end{array}$ & Very much disagree & $\begin{array}{l}\text { Neither } \\
\text { agree nor } \\
\text { disagree }\end{array}$ & $\begin{array}{c}\text { Very much } \\
\text { agree }\end{array}$ & Completely agree \\
\hline & 1 & 2 & 3 & 4 & 5 \\
\hline \multirow{2}{*}{$\begin{array}{l}\text { End-anchored } \\
\text { 5-point Likert }\end{array}$} & $\begin{array}{c}\text { Completely } \\
\text { disagree }\end{array}$ & & & & Completely agree \\
\hline & 1 & 2 & 3 & 4 & 5 \\
\hline
\end{tabular}

3.There are more advanced data imputation methods but this simple alternative method was used here since the number of missing data was small.

4.28 items of the SPOS can be seen in Appendix A. 


\begin{tabular}{|c|c|c|c|c|c|c|}
\hline \multirow{2}{*}{$\begin{array}{l}\text { Fully-labeled } \\
\text { 6-point Likert }\end{array}$} & $\begin{array}{c}\text { Completely } \\
\text { disagree }\end{array}$ & $\begin{array}{l}\text { Very much } \\
\text { disagree }\end{array}$ & $\begin{array}{l}\text { Slightly } \\
\text { disagree }\end{array}$ & $\begin{array}{c}\text { Slightly } \\
\text { agree }\end{array}$ & Very much agree & Completely agree \\
\hline & 1 & 2 & 3 & 4 & 5 & 6 \\
\hline \multirow{2}{*}{$\begin{array}{l}\text { End-anchored } \\
\text { 6-point Likert }\end{array}$} & $\begin{array}{c}\text { Completely } \\
\text { disagree }\end{array}$ & & & & & Completely agree \\
\hline & 1 & 2 & 3 & 4 & 5 & 6 \\
\hline
\end{tabular}

Prior to the analyses, in order to make responses to the 5-point and 6-point Likert scale formats comparable, it was necessary to recode the response categories so that they spanned the same range (Adelson and McCoach, 2010: 800), had equal intervals, and had the same expected value ${ }^{5}$. For the 5 -point Likert scale, the recoding for the responses was done as; -2.5 for completely disagree, -1.25 for very much disagree, 0 for neither agree nor disagree, 1.25 for very much agree, and 2.5 for completely agree. For the 6-point Likert scale, the recoding for the responses was done as; -2.5 for completely disagree, -1.5 for very much disagree, -0.5 for slightly disagree, 0.5 for slightly agree, 1.5 for very much agree, and 2.5 for completely agree.

\subsection{Item Analyses}

Item analyses according to classical test theory are conducted in order to evaluate the quality and the usefulness of SPOS items and to determine the best items for inclusion in SPOS for the second study. There are various methods for conducting item analysis. Among these methods, we chose the method which involves the examination of: (1) item difficulty (attractiveness) indices and (2) item/total-test-score correlations. Positive results of item analyses would imply that the scale is measuring the participants' true scores with sufficient precision (Mellenbergh, 2011: 170).

In typical performance scales (i.e. scales designed to measure attitudes, personal traits, personality, etc.), some items are more easily endorsed by participants compared to other items. The extent to which an item is easily endorsed is usually referred to as item difficulty, item easiness or item attractiveness. Item means across participants are usually used to define item difficulty (attractiveness) in classical test theory (Mellenbergh, 2011: 151). A high value of item mean would indicate an attractive (easy) item whereas a low mean value would indicate a difficult to endorse item. In the present study, item means were calculated for each version of SPOS and were ordered from the easiest to the most difficult one, in order to examine item difficulties. These difficulty rank orders of items across the four different forms of SPOS were compared. Spearman rank-order correlation coefficients (rho) were calculated in order to ascertain whether rank orders of item difficulties are similar across the survey versions.

In classical test theory, there are various ways of operationalizing an item's discrimination. Two most widely used statistics are: (1) the item discrimination index and (2) the item-total correlation. Using these two statistics, the scale developer hopes to find the items that discriminate well among participants with varying levels of the construct being measured. A scale that is composed of such discriminating items would provide the most information possible about differences between the participants' levels of the trait measured (Allen and Yen, 2002: 120; Furr and Bacharach, 2008: 161). In the present study, item/total-test-score correlation is the preferred statistics to determine the degree to which responses to each item of SPOS are related to responses given to other items of SPOS. Corrected item-total correlations between items and their total scores were calculated separately for each of the versions of SPOS. These correlations were ordered from the highest to the lowest for each version. Rank orders of corrected item-total correlations across the four different forms of SPOS were examined for the purpose of determining items with low item-total correlations.

5. Here, expected value can be operationally defined as the sum of the values of all possible categories. 
Spearman's rho correlations were calculated to determine whether the ranking of item-total correlations remained the same across the four versions of SPOS ${ }^{6}$.

\subsection{Reliability and Factor Analyses}

In order to evaluate the internal consistency reliabilities of SPOS with different scale designs, reliability analyses were conducted. For all the versions of SPOS, alpha coefficients (Cronbach's Alpha) were calculated. Finally, EFA was conducted using principal axis factoring extraction method to test whether SPOS measures a unidimensional construct.

\subsection{Results}

\subsubsection{Item Difficulty Analyses}

As presented in Table 2 below, four randomly distributed forms of SPOS with (1) fullylabeled, 5-point Likert scale, (2) end-anchored, 5-point Likert scale, (3) fully-labeled, 6-point Likert scale, and (4) end-anchored, 6-point Likert scale were completed by 70, 65, 65, and 76 participants, respectively.

Table 2: Label Type and Number of Categories Cross Tabulation

\begin{tabular}{|r|r|c|c|c|}
\hline \multicolumn{2}{|c|}{} & \multicolumn{2}{|c|}{$\begin{array}{l}\text { Number of } \\
\text { Categories }\end{array}$} \\
\cline { 3 - 5 } & $\mathbf{5}$ & $\mathbf{6}$ & \multicolumn{1}{|c|}{ Total } \\
\hline \multirow{2}{*}{ Label Type } & Fully-Labeled & 70 & 65 & 135 \\
\cline { 2 - 5 } & End-Anchored & 65 & 76 & 141 \\
\hline & Total & 135 & 141 & $\mathbf{2 7 6}$ \\
\hline
\end{tabular}

Item means were calculated separately for each version of SPOS and were ordered from the easiest to the most difficult one. These item orders are displayed in Table 3 below.

Table 3: Rank-orders of Item Means

\begin{tabular}{|c|c|c|c|c|}
\hline $\begin{array}{l}\text { Item } \\
\text { No }\end{array}$ & $\begin{array}{l}\text { Fully-labeled } \\
\text { 5-point Likert } \\
\text { Scale }\end{array}$ & $\begin{array}{l}\text { End-anchored } \\
\text { 5-point Likert } \\
\text { Scale }\end{array}$ & $\begin{array}{l}\text { Fully-labeled } \\
\text { 6-point Likert } \\
\text { Scale }\end{array}$ & $\begin{array}{l}\text { End-anchored } \\
\text { 6-point Likert } \\
\text { Scale }\end{array}$ \\
\hline 1 & 7 & 7 & 8 & 5 \\
\hline 2 & 10 & 20 & 13 & 12 \\
\hline 3 & 21 & 23 & 20 & 24 \\
\hline 4 & 2 & 2 & 5 & 3 \\
\hline 5 & 13 & 10 & 7 & 7 \\
\hline 6 & 27 & 24 & 24 & 25 \\
\hline 7 & 8 & 8 & 10 & 10 \\
\hline 8 & 26 & 22 & 23 & 22 \\
\hline 9 & 11 & 11 & 9 & 8 \\
\hline 10 & 12 & 12 & 18 & 14 \\
\hline 11 & 4 & 5 & 3 & 2 \\
\hline 12 & 16 & 14 & 15 & 18 \\
\hline 13 & 15 & 26 & 19 & 23 \\
\hline 14 & 19 & 16 & 11 & 15 \\
\hline 15 & 24 & 21 & 21 & 19 \\
\hline
\end{tabular}

6.IBM SPSS Statistics Version 20 has been used to conduct all of the analyses in this study. 


\begin{tabular}{|c|c|c|c|c|}
\hline 16 & 9 & 9 & 12 & 11 \\
\hline 17 & 22 & 18 & 25 & 20 \\
\hline 18 & 5 & 3 & 4 & 4 \\
\hline 19 & 18 & 13 & 16 & 16 \\
\hline 20 & 14 & 19 & 14 & 13 \\
\hline 21 & 20 & 17 & 17 & 17 \\
\hline 22 & 1 & 1 & 1 & 1 \\
\hline 23 & 6 & 4 & 6 & 9 \\
\hline 24 & 25 & 25 & 26 & 26 \\
\hline 25 & 23 & 27 & 27 & 27 \\
\hline 26 & 17 & 15 & 22 & 21 \\
\hline 27 & 28 & 28 & 28 & 6 \\
\hline 28 & 3 & 6 & 2 & 28 \\
\hline
\end{tabular}

Item difficulties across four forms of SPOS were compared. For all four versions of SPOS, Item 22 was the easiest one and Item 27 was the most difficult one. As it can be seen in Table 4, Items $4,11,18,22,23$, and 28 are among the easiest and Items 6, 8, 24, 25, and 27 are among the most difficult items for all the versions of SPOS. The difficulty rank orders of items across the four different forms of SPOS were almost the same, indicating that these four forms of SPOS are comparable.

In order to quantify the extent to which rank orders of item difficulties are similar across survey versions, Spearman Rank-order Correlation Coefficients were calculated. Correlations ranged between .89 and $.96(p<.001)$. The results are shown in Table 4 below. The correlations are very high indicating that difficulty/easiness levels of items do not vary substantially across survey versions.

Table 4: Spearman Rank-order Correlation Coefficients of Item Difficulties across SPOS Versions

\begin{tabular}{|c|c|c|c|c|} 
& Fully-labeled & End-anchored & Fully-labeled & End-anchored \\
\hline Fully-labeled & $\begin{array}{c}\text { 5-point Likert } \\
\text { Scale }\end{array}$ & $\begin{array}{c}\text { 5-point Likert } \\
\text { Scale }\end{array}$ & $\begin{array}{c}\text { 6-point Likert } \\
\text { Scale }\end{array}$ & $\begin{array}{c}\text { 6-point Likert } \\
\text { Scale }\end{array}$ \\
\hline $\begin{array}{c}\text { 5-point Likert } \\
\text { Scale }\end{array}$ & - & - & - & - \\
\hline $\begin{array}{c}\text { End-anchored } \\
\text { 5-point Likert } \\
\text { Scale }\end{array}$ & .89 & - & - & - \\
\hline $\begin{array}{c}\text { Fully-labeled } \\
\text { 6-point Likert } \\
\text { Scale }\end{array}$ & .92 & .90 & - & \\
\hline $\begin{array}{c}\text { End-anchored } \\
\text { 6-point Likert } \\
\text { Scale }\end{array}$ & .93 & .93 & & \\
\hline
\end{tabular}




\subsubsection{Item Discrimination Analyses}

Corrected item-total correlations between items and their total scores were calculated separately for each of the versions of SPOS. These correlations were ordered from the highest to the lowest for each version. The ranking of corrected item-total correlations across four forms of SPOS are presented in Table 5 below.

Table 5: Corrected Item-Total Correlations Ranking for the Four Different Versions of SPOS

\begin{tabular}{|c|c|c|c|c|c|c|c|c|}
\hline \multirow[b]{2}{*}{ Rank } & \multicolumn{2}{|c|}{$\begin{array}{l}\text { Fully-labeled } \\
\text { 5-point Likert } \\
\text { Scale }\end{array}$} & \multicolumn{2}{|c|}{$\begin{array}{l}\text { End-anchored } \\
\text { 5-point Likert } \\
\text { Scale }\end{array}$} & \multicolumn{2}{|c|}{$\begin{array}{l}\text { Fully-labeled } \\
\text { 6-point Likert } \\
\text { Scale }\end{array}$} & \multicolumn{2}{|c|}{$\begin{array}{l}\text { End-anchored } \\
\text { 6-point Likert } \\
\text { Scale }\end{array}$} \\
\hline & Item No & $r$ & Item No & $r$ & Item No & $r$ & Item No & $r$ \\
\hline 1 & 8 & .88 & 17 & .84 & 8 & .87 & 8 & .86 \\
\hline 2 & 21 & .84 & 8 & .79 & 3 & .85 & 17 & .81 \\
\hline 3 & 14 & .83 & 1 & .77 & 17 & .83 & 9 & .81 \\
\hline 4 & 7 & .82 & 14 & .73 & 7 & .82 & 16 & .77 \\
\hline 5 & 23 & .79 & 28 & .7 & 16 & .82 & 23 & .76 \\
\hline 6 & 27 & .79 & 21 & .69 & 21 & .82 & 21 & .76 \\
\hline 7 & 1 & .78 & 23 & .68 & 23 & .80 & 3 & .71 \\
\hline 8 & 16 & .75 & 18 & .67 & 6 & .79 & 19 & .70 \\
\hline 9 & 15 & .74 & 3 & .67 & 14 & .77 & 28 & .70 \\
\hline 10 & 3 & .73 & 7 & .64 & 19 & .76 & 14 & .66 \\
\hline 11 & 18 & .73 & 27 & .63 & 1 & .75 & 1 & .65 \\
\hline 12 & 17 & .73 & 9 & .62 & 9 & .73 & 6 & .64 \\
\hline 13 & 5 & .73 & 16 & .60 & 28 & .71 & 7 & .64 \\
\hline 14 & 6 & .70 & 2 & .60 & 5 & .70 & 5 & .63 \\
\hline 15 & 26 & .65 & 5 & .58 & 15 & .69 & 26 & .61 \\
\hline 16 & 19 & .64 & 22 & .58 & 18 & .68 & 11 & .54 \\
\hline 17 & 13 & .62 & 26 & .54 & 24 & .68 & 22 & .54 \\
\hline 18 & 9 & .59 & 6 & .53 & 13 & .66 & 20 & .54 \\
\hline 19 & 2 & .58 & 12 & .52 & 11 & .64 & 2 & .52 \\
\hline 20 & 28 & .58 & 15 & .48 & 4 & .60 & 15 & .51 \\
\hline 21 & 12 & .53 & 19 & .47 & 27 & .60 & 27 & .49 \\
\hline 22 & 20 & .51 & 20 & .46 & 10 & .59 & 18 & .48 \\
\hline 23 & 24 & .45 & 11 & .41 & 26 & .57 & 13 & .45 \\
\hline 24 & 10 & .36 & 10 & .38 & 2 & .56 & 25 & .43 \\
\hline 25 & 11 & .32 & 13 & .31 & 12 & .54 & 12 & .43 \\
\hline 26 & 4 & .30 & 4 & .27 & 25 & .45 & 10 & .42 \\
\hline 27 & 22 & .29 & 24 & .21 & 20 & .45 & 4 & .41 \\
\hline 28 & 25 & .24 & 25 & .06 & 22 & .40 & 24 & .26 \\
\hline
\end{tabular}

The examination of rank orders of corrected item-total correlations across the four different forms of SPOS revealed that items $8,17,21$, and 23 had very high corrected itemtotal correlations across three or four different types of survey forms. It was also found that items $4,10,22,24$, and 25 had relatively low corrected item-total correlations across three 
or four different types of survey forms. Therefore, it might be considered to drop these five items from SPOS before continuing with subsequent analyses since they do not contribute much in differentiating participants in terms of their level of POS. However, at this point, these items were kept for further analyses to see whether scale reliability analyses would yield similar results.

Spearman's rho correlations were calculated to determine whether the ranking of itemtotal correlations are similar across the four different forms of SPOS. Results are displayed in Table 6 below. These results indicated that there is a high correlation between the ranked item-total correlations of four different scale designs of SPOS. The highest correlation was between the fully-labeled, 6-point Likert scale and the end-anchored, 6-point Likert Scale $(r=.78, p<.05)$. Items which have the highest and lowest correlations with the total score were almost the same for each type of scale designs of the survey. In support of item difficulty analysis results, it was found that these four different forms of SPOS are comparable.

Table 6: Spearman Rank-order Correlation Coefficients of Item Discriminations across SPOS Versions

\begin{tabular}{|c|c|c|c|c|}
\hline & $\begin{array}{c}\text { Fully- } \\
\text { labeled } \\
\text { 5-point } \\
\text { Likert }\end{array}$ & $\begin{array}{c}\text { End- } \\
\text { anchored } \\
\text { 5-point } \\
\text { Likert }\end{array}$ & $\begin{array}{c}\text { Fully- } \\
\text { labeled } \\
\text { 6-point } \\
\text { Likert }\end{array}$ & $\begin{array}{c}\text { End- } \\
\text { anchored } \\
\text { 6-point } \\
\text { Likert }\end{array}$ \\
\hline Fully-labeled & - & - & - & - \\
\hline 5-point Likert & .75 & - & & \\
\hline 5-point Likert & .75 & .65 & - & \\
\hline Fully-labeled & & .74 & .78 & \\
\hline 6-point Likert & .60 & & & \\
\hline End-anchored & & & & \\
\hline 6-point Likert & & & & \\
\hline
\end{tabular}

\subsubsection{Reliability Analyses}

Reliability analyses were conducted to examine the internal consistency reliabilities of SPOS with different scale designs. The results showed that alpha coefficients were very high for all of the four versions of SPOS indicating high internal consistency. The results are presented in Table 7 below.

\begin{tabular}{|c|c|}
\multicolumn{2}{|c|}{ Table 7: Reliability Statistics - First Analysis } \\
\hline Type of Scale & Coefficient Alpha \\
\hline Fully-labeled 5-point Likert & .951 \\
\hline End-anchored 5-point Likert & .930 \\
\hline Fully-labeled 6-point Likert & .962 \\
\hline End-anchored 6-point Likert & .943 \\
\hline
\end{tabular}

Item-total statistics were examined separately for each of the four versions to determine the items which have low item-total correlations and would contribute to coefficient alpha if they are deleted. Some items had low item-total correlations for all of the four versions of SPOS. These items were 4,10 , and 25 . Reliability analyses were conducted for the second time after eliminating these items. Alpha coefficients that were obtained are displayed in Table 8 below. 
Table 8: Reliability Statistics - Reduced Scale

\begin{tabular}{|c|c|}
\hline Type of Scale & Coefficient Alpha \\
\hline Fully-labeled 5-point Likert & .956 \\
\hline End-anchored 5-point Likert & .935 \\
\hline Fully-labeled 6-point Likert & .962 \\
\hline End-anchored 6-point Likert & .943 \\
\hline
\end{tabular}

Again the results indicated a high internal consistency for all the versions of SPOS. Although alpha coefficients were very high for all of the four versions of SPOS, item-total statistics were examined again separately for each of the four versions to determine the items which had low item-total correlations. Items that would increase coefficient alpha if they were deleted were, 11, 22, and 24 for the fully-labeled, 5-point Likert scale, 13 and 24 for the end-anchored, 5-point Likert scale, 20 and 22 for the fully-labeled, 6-point Likert scale, and 12, 13, and 24 for the end-anchored, 6-point Likert scale. However, these items were retained for the factor analysis, since they were not common across all versions and the coefficients of internal consistency were already very high.

\subsubsection{Factor Analyses}

Since the sample sizes of the four types of scale designs were not sufficient for separate factor analyses, the overall sample was separately divided into two groups; first, in terms of the number of points of Likert-type options (5-point Likert scale vs. 6-point Likert scale) and then, in terms of anchor labels (fully-labeled vs. end-anchored) used in the scale. In other words, the four subsamples were collapsed (separately); first, according to the number of categories, then, according to the anchor labels. Therefore, in the first step, respondents who received 5-point fully labeled and 5-point end-anchored versions of the scale were combined to form the 5-point Likert scale group and 6-point fully labeled and 6-point end-anchored subsamples were combined to form the 6-point Likert scale group. In the second step, 5-point fully labeled and 6-point fully labeled subsamples were combined to form the fully-labeled group and 5-point end-anchored and 6-point end-anchored subsamples were combined to form the end-anchored group. Separate factor analyses were conducted for each of the two groups in the first step and for each of the two groups in the second step ${ }^{7}$.

At first, the data was split in terms of the number of points of Likert-type options (5-point Likert scale and 6-point Likert scale). Exploratory factor analysis was conducted using principal axis factoring method with no rotation. KMO and Bartlett's test results were .928 and 2039.628, respectively $(p<.001)$ for the 5-point Likert scale. For the 6-point Likert scale, on the other hand, KMO and Bartlett's test results were .931 and 2039.334, respectively ( $p<.001)$. KMO values close to 1 generally indicate that factor analysis can be conducted with the data. For Bartlett's test of sphericity, small values of significance level are desired (less than .05) which would indicate that factor analysis may be useful with the data (IBM Knowledge Center, 2014). Since we obtained adequate KMO indices and significance levels below .05, we concluded that our data was suitable to conduct factor analyses.

The number of factors to retain should be determined prior to factor analysis. Kaiser's eigenvalue greater than 1 criterion (1960) is adopted in this study which suggested four factors ${ }^{8}$. However, the analysis revealed that most of the items loaded highly on the presumed $7 \mathrm{As}$ a result of these procedures, four new groups are created. The sizes of these four new groups are now adequate for an exploratory factor analysis. But, contrary to the original 4 subsamples, these new groups are not mutually exclusive.

8.Despite its deficiencies for determining the number of factors in exploratory factor analysis (Fabrigar, 1999: 278), this method has been adopted here because of its simplicity and widespread use. There are other approaches for determining the number of factors to retain, such as, Cattell's scree test (Cattell, 1966) or Horn's parallel analysis (Horn, 1965) which overcome these problems (for a detailed discussion of other methods, see 
POS factor which suggests a single factor rather than four ${ }^{9}$. Some of the items had very low loadings (below the cut-off point of .4) either on the presumed POS factor or on the all four factors extracted. These items were 11, 13, 22, and 24 for the 5-point Likert scale, and 24 for the 6-point Likert scale. The results of these analyses are presented in Tables 9 and 10 below.

Table 9: Factor Matrix - 5-point Likert Scale

\begin{tabular}{|c|c|c|c|c|}
\hline \multirow{2}{*}{$\begin{array}{c}\text { Item } \\
\text { No }\end{array}$} & \multicolumn{4}{|c|}{ Factor } \\
\hline & 1 & 2 & 4 & \\
\hline 8 & .865 & -.102 & -.101 & -.020 \\
\hline 14 & .817 & .101 & -.321 & -.006 \\
\hline 17 & .816 & -.048 & -.049 & .131 \\
\hline 1 & .809 & .050 & .093 & -.001 \\
\hline 21 & .789 & .139 & .148 & -.134 \\
\hline 23 & .769 & .077 & .179 & .018 \\
\hline 7 & .763 & -.189 & .019 & -.081 \\
\hline 18 & .733 & -.097 & -.064 & .157 \\
\hline 27 & .731 & -.152 & .091 & -.138 \\
\hline 3 & .716 & -.143 & .110 & -.246 \\
\hline 16 & .709 & -.108 & .277 & .086 \\
\hline 5 & .680 & -.107 & -.128 & .032 \\
\hline 15 & .660 & -.151 & -.062 & .154 \\
\hline 6 & .647 & -.056 & -.143 & .005 \\
\hline 26 & .644 & -.153 & .159 & .182 \\
\hline 9 & .644 & -.129 & .027 & -.111 \\
\hline 28 & .641 & .291 & .185 & .234 \\
\hline 2 & .611 & .076 & -.129 & -.048 \\
\hline 19 & .597 & -.200 & -.146 & -.051 \\
\hline 12 & .548 & .407 & -.264 & -.051 \\
\hline 20 & .518 & .445 & .240 & -.370 \\
\hline 13 & .461 & -.040 & -.427 & -.107 \\
\hline 11 & .369 & .042 & .368 & .095 \\
\hline 24 & .328 & -.097 & .115 & .072 \\
\hline 22 & .435 & .456 & -.130 & .274 \\
\hline
\end{tabular}

Fabrigar, 1999: 278-279).

9.This result coincides with the findings of scree test which clearly indicated a single factor for all four groups. However, factor analysis results for the four-factor solution are reported here, since the factor loadings of the first factor of the four-factor solution were extremely highly correlated with those of the single-factor solution ( $r>99$ for all four groups). 
Table 10: Factor Matrix - 6-point Likert Scale

\begin{tabular}{|c|c|c|c|c|}
\hline \multirow{2}{*}{$\begin{array}{l}\text { Item } \\
\text { No }\end{array}$} & \multicolumn{4}{|c|}{ Factor } \\
\hline & 1 & 2 & 3 & 4 \\
\hline 8 & .891 & -.111 & -.002 & -.054 \\
\hline 17 & .854 & -.143 & -.042 & .060 \\
\hline 16 & .826 & -.041 & -.052 & -.291 \\
\hline 21 & .806 & -.176 & .087 & -.049 \\
\hline 23 & .804 & .112 & .068 & -.026 \\
\hline 9 & .796 & -.109 & .311 & -.040 \\
\hline 3 & .790 & -.154 & -.081 & .000 \\
\hline 19 & .745 & .230 & -.117 & -.086 \\
\hline 7 & .740 & -.040 & .047 & -.162 \\
\hline 1 & .732 & .042 & -.049 & -.119 \\
\hline 6 & .724 & .099 & -.288 & .024 \\
\hline 14 & .717 & .333 & -.120 & .195 \\
\hline 28 & .716 & -.003 & .053 & -.011 \\
\hline 5 & .664 & .159 & -.098 & .135 \\
\hline 26 & .641 & -.441 & -.036 & .354 \\
\hline 15 & .624 & -.220 & -.166 & -.054 \\
\hline 11 & .606 & -.118 & -.023 & .060 \\
\hline 18 & .594 & .152 & -.196 & -.291 \\
\hline 27 & .575 & -.363 & -.007 & -.049 \\
\hline 2 & .548 & .275 & -.141 & -.026 \\
\hline 13 & .525 & .239 & -.067 & -.040 \\
\hline 12 & .485 & .392 & .245 & .000 \\
\hline 22 & .483 & .262 & .289 & -.086 \\
\hline 24 & .445 & -.110 & .039 & -.162 \\
\hline 20 & .521 & -.009 & .537 & -.119 \\
\hline
\end{tabular}

Next, the data was split in terms of labeling anchors (fully-labeled and end-anchored). KMO and Bartlett's test results were .947 and 2416.899, respectively $(p<.001)$ for the fully-labeled scale. For the end-anchored scale, on the other hand, KMO and Bartlett's test results were .917 and 1982.577, respectively $(p<.001)$. KMO values were close to 1 and for the Bartlett's test of sphericity, significance levels were below .05 . Thus, we concluded that our data was suitable to conduct factor analyses.

The analysis again revealed that most of the items loaded highly on the presumed POS factor. Some of the items had very low loadings either on the presumed POS factor or on the all four factors extracted. These items were 11 and 22 for the fully-labeled scale, and 11, 12, 13 , and 24 for the end-anchored scale. The results of these analyses are displayed in Tables 11 and 12 below. 
Table 11: Factor Matrix - Fully-Labeled Scale

\begin{tabular}{|c|c|c|c|c|}
\hline \multirow{2}{*}{$\begin{array}{l}\text { Item } \\
\text { No }\end{array}$} & \multicolumn{4}{|c|}{ Factor } \\
\hline & 1 & 2 & 3 & 4 \\
\hline 8 & .894 & -.106 & -.004 & -.035 \\
\hline 7 & .832 & -.128 & .070 & -.150 \\
\hline 21 & .829 & .090 & .113 & .073 \\
\hline 17 & .813 & -.063 & .009 & .137 \\
\hline 23 & .813 & .166 & .121 & .029 \\
\hline 14 & .811 & .065 & -.336 & .105 \\
\hline 16 & .806 & -.071 & .256 & -.235 \\
\hline 3 & .795 & -.208 & .068 & -.119 \\
\hline 1 & .791 & .025 & .057 & -.082 \\
\hline 6 & .767 & -.093 & -.267 & -.169 \\
\hline 15 & .746 & -.176 & .157 & .104 \\
\hline 18 & .729 & .025 & -.114 & .013 \\
\hline 5 & .727 & -.043 & -.263 & -.142 \\
\hline 19 & .725 & -.123 & -.208 & -.082 \\
\hline 27 & .714 & -.311 & .030 & .240 \\
\hline 9 & .680 & -.051 & .218 & .067 \\
\hline 28 & .655 & .373 & .220 & .190 \\
\hline 26 & .649 & -.179 & .063 & .405 \\
\hline 13 & .639 & .040 & -.222 & .076 \\
\hline 2 & .586 & .080 & -.245 & .011 \\
\hline 24 & .562 & -.113 & .053 & -.073 \\
\hline 12 & .548 & .500 & -.144 & -.064 \\
\hline 20 & .497 & .345 & .202 & -.049 \\
\hline 11 & .488 & -.001 & .234 & -.308 \\
\hline 22 & .352 & .493 & -.026 & .061 \\
\hline
\end{tabular}

Table 12: Factor Matrix - End-Anchored Scale

\begin{tabular}{|c|c|c|c|c|}
\hline \multirow{3}{*}{$\begin{array}{l}\text { Item } \\
\text { No } \\
17 \\
\end{array}$} & \multicolumn{4}{|c|}{ Factor } \\
\hline & \multirow{2}{*}{$\begin{array}{c}1 \\
.857 \\
\end{array}$} & \multirow{2}{*}{\begin{tabular}{l|l}
$\mathbf{2}$ \\
-.024
\end{tabular}} & \multicolumn{2}{|c|}{4} \\
\hline & & & .045 & -.109 \\
\hline 8 & .855 & -.003 & -.088 & -.178 \\
\hline 23 & .770 & -.049 & .044 & .233 \\
\hline 21 & .760 & -.205 & -.159 & .091 \\
\hline 9 & .756 & .023 & -.296 & -.148 \\
\hline 1 & .745 & -.029 & .099 & .173 \\
\hline 28 & .731 & -.194 & .245 & .270 \\
\hline 16 & .730 & -.085 & .101 & -.221 \\
\hline 3 & .723 & -.106 & -.091 & -.032 \\
\hline 14 & .715 & .365 & .052 & .064 \\
\hline 7 & .668 & .009 & -.163 & -.299 \\
\hline 26 & .628 & -.375 & .007 & -.064 \\
\hline 19 & .617 & .172 & .036 & -.030 \\
\hline 5 & .609 & .082 & .166 & -.023 \\
\hline 6 & .606 & .078 & .249 & -.055 \\
\hline
\end{tabular}




\begin{tabular}{|r|r|r|r|r|}
\hline 18 & $\mathbf{. 5 9 5}$ & .036 & .285 & .032 \\
\hline 27 & $\mathbf{. 5 8 2}$ & -.201 & -.221 & -.004 \\
\hline 2 & $\mathbf{. 5 7 3}$ & .230 & .095 & .069 \\
\hline 22 & $\mathbf{. 5 6 0}$ & .134 & -.044 & .134 \\
\hline 20 & $\mathbf{. 5 3 8}$ & -.040 &.$- \mathbf{5 1 6}$ & .248 \\
\hline 15 & $\mathbf{. 5 2 0}$ & -.049 & .271 & -.097 \\
\hline 12 & $\mathbf{. 4 7 9}$ & $\mathbf{. 4 4 0}$ & -.139 & .099 \\
\hline 11 & $\mathbf{. 4 7 5}$ & -.289 & .034 & -.073 \\
\hline 24 & .239 & -.201 & .062 & .132 \\
\hline 13 & $\mathbf{. 3 8 7}$ & $\mathbf{. 4 5 6}$ & -.048 & -.079 \\
\hline
\end{tabular}

After these first analyses, a series of factor analyses were conducted and items 11, 12, 13, 20, 22, and 24 were eliminated in these steps. KMO and Bartlett's test results were .966 and 3439.994 , respectively $(p<.001)$, leading us to conclude that our data is suitable to conduct factor analysis. In the final factor analysis, all of the four versions of SPOS were included. The results of the factor analyses are presented in Tables 13 and 14 below.

Table 13: Factor Matrix - All Versions of SPOS Included

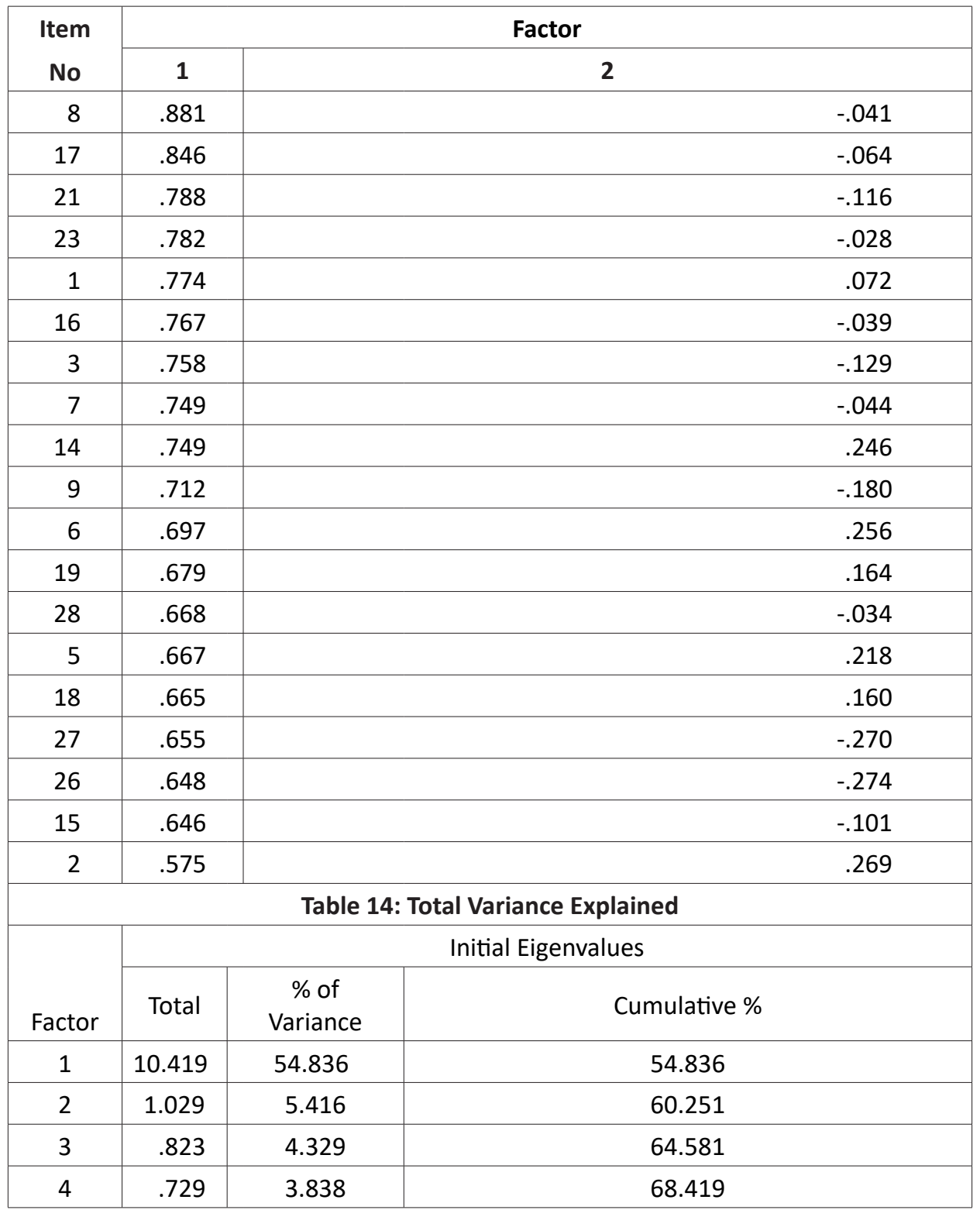




\begin{tabular}{|c|c|c|c|}
\hline 5 & .724 & 3.812 & 72.231 \\
\hline 6 & .571 & 3.003 & 75.234 \\
\hline 7 & .550 & 2.897 & 78.131 \\
\hline 8 & .512 & 2.694 & 80.825 \\
\hline 9 & .489 & 2.572 & 83.397 \\
\hline 10 & .445 & 2.341 & 85.738 \\
\hline 11 & .410 & 2.157 & 87.895 \\
\hline 12 & .383 & 2.018 & 89.913 \\
\hline 13 & .336 & 1.770 & 91.684 \\
\hline 14 & .312 & 1.643 & 93.327 \\
\hline 15 & .294 & 1.548 & 94.875 \\
\hline 16 & .285 & 1.499 & 96.374 \\
\hline 17 & .261 & 1.375 & 97.749 \\
\hline 18 & .242 & 1.272 & 99.021 \\
\hline 19 & .186 & .979 & 100.000 \\
\hline
\end{tabular}

This final analysis indicated that a single factor accounted for $52.6 \%$ of the total variance whereas a possible second factor accounted only for $2.8 \%$. All of the POS items that were retained loaded highly on the presumed "Perceived Organizational Support" factor, providing support that a unidimensional factor structure underlies the responses to SPOS items. Finally, a reliability analysis was conducted for the remaining 19 items. This analysis resulted in a coefficient alpha of .95, with item-total correlations ranging from .56 to .86, demonstrating high internal consistency for SPOS.

\section{STUDY II}

In Study I, psychometric properties of various forms of SPOS were compared and the optimal number of scale points for the Likert-type response format was determined. Since fully-labeled, 6-point Likert scale had the highest internal consistency among all the versions of SPOS, this version of the scale has been adopted in Study II.

In Study II, test-retest reliability and unidimensionality of the 16-item version of SPOS (17item version of SPOS without Item 2) was investigated. Test-retest reliability is a method for finding the consistency of test scores which requires the administration of a test to same individuals on two occasions separated by a time interval (Furr, 2011: 47; Murphy and Davidshofer, 2005: 123; Streiner and Norman, 2008: 182). The test-retest procedure provides a reasonable estimate of reliability when the construct measured is stable and when we can assume that the true scores do not change during a test-retest interval (Furr, 2011: 47; Furr and Bacharach, 2008: 109). Since POS is a global belief that employees form based on their workplace experiences that accumulate over time (Aselage and Eisenberger, 2003: 505; Shore and Shore, 1995: 149-150), it can be assumed that participants' level of SPOS would remain more or less constant between two occasions of the scale administration.

\subsection{Participants}

New faculty members including professors, lecturers, teaching and research assistants and instructors, and administrative staff of state and private universities located in two different cities (Istanbul and Gaziantep) in Turkey were recruited to participate in the test-retest study. In the first wave, SPOS was administered to 86 participants. Of these participants, 79 completed SPOS in the second wave, resulting in a low attrition rate ${ }^{10}$ of $8 \%(n=7)$.

10 Reaching low attrition rate is desired in repeated measure designs. 
In test-retest reliability analysis, the reliability coefficient is the correlation between the scores obtained during the two administrations of the test (Anastasi and Urbina, 1997: 92). An appropriate time interval should be selected which is not too short so that participants do not remember their former responses and which is not too long so that the phenomenon being measured is unlikely to change between the first test and the retest. There is no exact length of retest interval suggested by experts and it can range from an hour to a year, but an interval of 2 to 14 days is usually considered acceptable (Streiner and Norman, 2008: 182). In the present study, the time interval between the two administrations ranged from 8 days to 15 days.

\subsection{Instrument}

In Study I, four forms of SPOS with (1) fully-labeled, 5-point Likert scale, (2) end-anchored, 5-point Likert scale, (3) fully-labeled, 6-point Likert scale, and (4) end-anchored, 6-point Likert scale, were administered. Reliability analyses revealed that the fully-labeled Likert scale had slightly higher internal consistency reliability than the end-anchored scale. Furthermore, results indicated that the fully-labeled, 6-point Likert scale had a slightly higher reliability coefficient (Cronbach's alpha $=.962$ ) than the end-anchored, 6-point Likert scale. Since the fully-labeled 6-point Likert scale had the highest internal consistency among all the versions of SPOS, in Study II, this version of the scale design has been adopted.

In Study I, reliability analysis revealed that for all of the four versions of SPOS, items 4, 10, and 25 had low item-total correlations and would raise coefficient alpha if they were deleted. These items were eliminated. After item analyses, a series of factor analyses were conducted and items $24,11,22,13,20$, and 12 were eliminated which had very low loadings on the presumed POS factor (below the cut-off point .4). These discarded items in Study I coincide with the items that were not included in the 17-item version of SPOS that Eisenberger et al. (1986: 502) recommended as a shorter version of the scale. Thus, we decided to continue our investigation with the 17-item version of SPOS. However, as it has been in Study I, Item 2 from the 17-item version of SPOS ("If the organization could hire someone to replace me at a lower salary it would do so") was not included in the scale since this item is about employee lay-off and replacement and becomes meaningless when it is administered to a sample which consists of faculty members and administrative staff of state and private universities. Thus, in Study II, test-retest reliability of the 16-item version of SPOS was examined. Of the 16 items, 6 were reverse-worded items and the remaining 10 were straightforwardly-worded items ${ }^{11}$.

\subsection{Analyses}

For both administrations of SPOS, internal consistency reliabilities were estimated. Corrected item-total correlations were examined in order to determine items with high and low item-total correlations in both administrations of SPOS. The correlation between the total scores obtained from the two administrations of the test was calculated to determine the test-retest reliability of SPOS. Distributions of total scores for test and retest sessions were examined. Each item's Time-I and Time-II correlations were investigated. Item means for Time-I and Time-II were ordered from the easiest to the most difficult one for the purpose of examining item difficulties across two administrations of SPOS ${ }^{12}$.

\subsection{Results}

For the first wave, reliability analysis resulted in a coefficient alpha of .96, with corrected item-total correlations ranging from .594 to .898 with a median of .784. For the second wave, reliability analysis resulted in a coefficient alpha of .972, and item-total correlations ranged from .701 to .894 with a median of .839 . In the first wave, .8 or above corrected item-total

11.16-item version of the SPOS is presented in Appendix B.

12.IBM SPSS Statistic Version 20 has been used to conduct all of the analyses in this study. 
correlations were obtained for items $7,14,1,11,10$, and 6 . In the second wave, almost all of the items had high corrected item-total correlations and items 11, 10, 7, and 14 were among these ones, as it has been in the first wave. Items 7, 11, and 14 also had very high corrected item-total correlations across three or four different types of survey forms also in Study I. Time-I and Time-II item-total statistics are presented in Table 15 below.

Table 15: Time-I and Time-II Item-Total Statistics

\begin{tabular}{|c|c|c|c|c|}
\hline & \multicolumn{2}{|c|}{$\begin{array}{c}\text { Time-I Item-Total Statistics for the 16-item } \\
\text { SPOS }(\alpha=.960)\end{array}$} & $\begin{array}{c}\text { Time-II Item-Total Statistics for the 16-item } \\
\text { SPOS }(\alpha=.972)\end{array}$ \\
\hline $\begin{array}{c}\text { Item } \\
\text { No }\end{array}$ & $\begin{array}{c}\text { Corrected Item-Total } \\
\text { Correlation }\end{array}$ & $\begin{array}{c}\text { Coefficient Alpha if } \\
\text { Item Deleted }\end{array}$ & $\begin{array}{c}\text { Corrected Item-Total } \\
\text { Correlation }\end{array}$ & $\begin{array}{c}\text { Coefficient Alpha } \\
\text { if Item Deleted }\end{array}$ \\
\hline 1 & .815 & .956 & .704 & .972 \\
\hline 2 & .695 & .958 & .701 & .972 \\
\hline 3 & .788 & .956 & .836 & .970 \\
\hline 4 & .663 & .959 & .815 & .970 \\
\hline 5 & .679 & .958 & .740 & .971 \\
\hline 6 & .800 & .956 & .818 & .970 \\
\hline 7 & .898 & .954 & .851 & .970 \\
\hline 8 & .754 & .957 & .856 & .970 \\
\hline 9 & .802 & .956 & .873 & .969 \\
\hline 10 & .803 & .956 & .861 & .969 \\
\hline 11 & .814 & .956 & .894 & .969 \\
\hline 12 & .723 & .958 & .842 & .970 \\
\hline 13 & .746 & .957 & .767 & .971 \\
\hline 14 & .827 & .956 & .853 & .970 \\
\hline 15 & .594 & .960 & .808 & .970 \\
\hline 16 & .780 & .957 & .863 & .970 \\
\hline
\end{tabular}

Short version of SPOS with 16-items demonstrated a high test-retest reliability $(r=.916)$. Figure 1 below displays the values for Time-I and Time-II total score data. The scatterplot of the data provides a clear presentation that there is a strong positive linear relation between the total scores of the two administrations of SPOS.

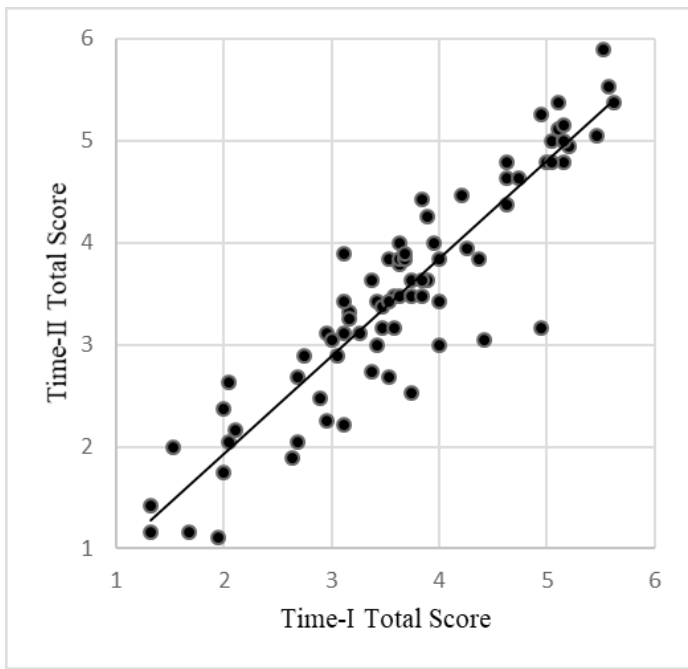




\section{Figure 1: Time-I - Time-II Total Score Correlation}

When each item's Time-I and Time-II correlations were investigated, results revealed that items $6,16,14,11$, and 9 had the highest correlations ranging from .752 to .806 . Item 5 had the lowest Time-I - Time-II correlation ( $r=.607, \rho=.602)$. Each item's Time-I and Time-II correlations are displayed in Table 16 below.

Table 16: Items' Time-I and Time-II Correlations

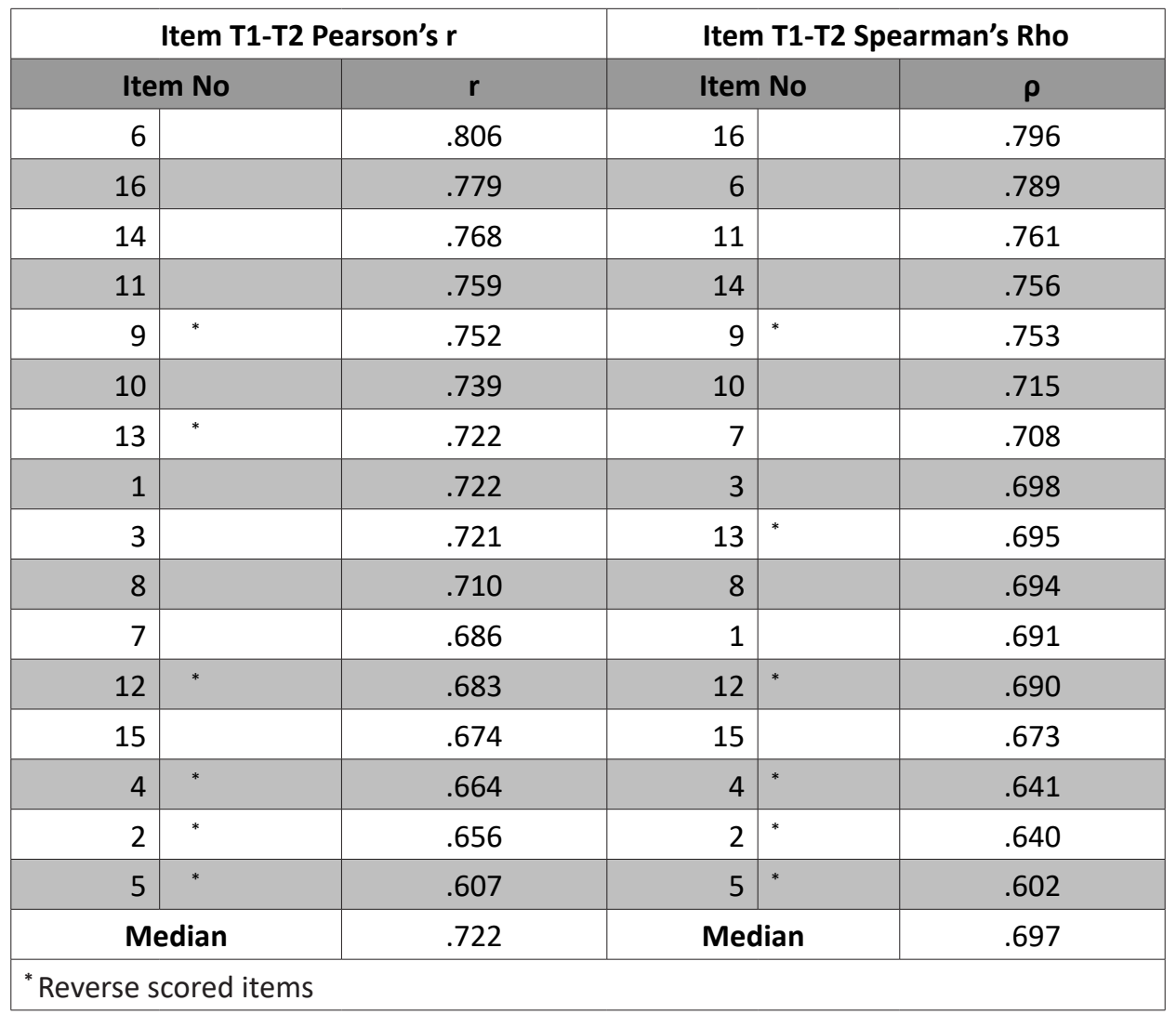

As displayed in Table 17 below, very low and non-significant skewness and kurtosis values for both sessions indicate that total scores are approximately normally distributed both in Time-I and Time-II.

Table 17: Descriptive Statistics for Time-I and Time-II Total Scores

\begin{tabular}{|l|r|l|c|}
\hline \multicolumn{2}{|c|}{ Time-I } & \multicolumn{1}{c|}{ Time-II } & \\
\hline Mean & 3.66 & Mean & 3.50 \\
\hline Median & 3.63 & Median & 3.44 \\
\hline Std. Deviation & 1.09 & Std. Deviation & 1.14 \\
\hline Minimum & 1.25 & Minimum & 1.00 \\
\hline Maximum & 5.75 & Maximum & 5.94 \\
\hline Range & 4.50 & Range & 4.94 \\
\hline Skewness & -.14 & Skewness & -.09 \\
\hline Std. Error of Skewness & .27 & Std. Error of Skewness & .27 \\
\hline Kurtosis & -.40 & Kurtosis & -.43 \\
\hline Std. Error of Kurtosis & .53 & Std. Error of Kurtosis & .53 \\
\hline
\end{tabular}

Item means were calculated for Time-I and Time-II, and were ordered from the easiest to the most difficult one. The order of item difficulties (high value of item mean would indicate 
an easy item and vice versa) was almost the same across two occasions. As it can be seen in Table 18 below, 15, 1, 12, 6, and 2 are among the easiest and 11, 5, and 16 are among the most difficult items for both occasions, indicating the stability of item difficulties across two administrations.

Table 18: Item Difficulties across Two Sessions

\begin{tabular}{|r|c|r|r|r|c|}
\hline \multicolumn{3}{|c|}{ Time-I } & \multicolumn{3}{c|}{ Time-II } \\
\hline Item No & Mean & Std. Deviation & Item No & Mean & Std. Deviation \\
\hline $\mathbf{1 5}$ & 4.28 & 1.26 & $\mathbf{1 5}$ & 4.05 & 1.18 \\
\hline $\mathbf{1}$ & 4.22 & 1.31 & $\mathbf{1}$ & 4.00 & 1.29 \\
\hline $\mathbf{1 2}$ & 4.04 & 1.59 & $\mathbf{6}$ & 3.82 & 1.20 \\
\hline $\mathbf{6}$ & 3.99 & 1.24 & $\mathbf{1 2}$ & 3.75 & 1.50 \\
\hline $\mathbf{2}$ & 3.85 & 1.53 & $\mathbf{2}$ & 3.71 & 1.48 \\
\hline $\mathbf{8}$ & 3.84 & 1.29 & $\mathbf{1 3}$ & 3.62 & 1.30 \\
\hline $\mathbf{1 0}$ & 3.78 & 1.32 & $\mathbf{8}$ & 3.58 & 1.29 \\
\hline $\mathbf{4}$ & 3.62 & 1.43 & $\mathbf{1 0}$ & 3.54 & 1.44 \\
\hline $\mathbf{1 3}$ & 3.62 & 1.45 & $\mathbf{4}$ & 3.46 & 1.40 \\
\hline $\mathbf{9}$ & 3.57 & 1.61 & $\mathbf{1 4}$ & 3.39 & 1.35 \\
\hline $\mathbf{3}$ & 3.53 & 1.32 & $\mathbf{7}$ & 3.38 & 1.39 \\
\hline $\mathbf{1 4}$ & 3.52 & 1.32 & $\mathbf{9}$ & 3.29 & 1.54 \\
\hline $\mathbf{7}$ & 3.44 & 1.33 & $\mathbf{3}$ & 3.22 & 1.27 \\
\hline $\mathbf{1 1}$ & 3.41 & 1.41 & $\mathbf{1 1}$ & 3.20 & 1.41 \\
\hline $\mathbf{5}$ & 3.10 & 1.46 & $\mathbf{5}$ & 3.09 & 1.39 \\
\hline $\mathbf{1 6}$ & 2.75 & 1.14 & $\mathbf{1 6}$ & 2.86 & 1.25 \\
\hline & & & & & \\
\hline
\end{tabular}

\section{DISCUSSION}

The present study is one of the few studies that have empirically investigated the relationship of scale design with item characteristics, internal consistency reliability, and construct validity of the Survey of Perceived Organizational Support. According to the results, the number of response categories and the way they are anchored did not create a dramatic impact on the participants' responses to SPOS items. Alpha coefficients were very high for all of the four different scale designs of SPOS. Nevertheless, a comparison of alpha coefficients of the four different scale designs of SPOS revealed that the fully-labeled, 6-point Likert scale had the highest reliability coefficient (Cronbach's alpha $=.962$ ) although the difference was not high.

In Study I, EFA provided support for the unidimensionality of SPOS, a finding that is consistent with the results of previous studies conducted to examine the factor structure of SPOS (e.g. Andrews and Kacmar, 2001: 355, [15-item version]; Bishop et al., 2005: 166, [7item version]; Eisenberger et al., 1986: 500-507, [36-item and 17-items versions of the SPOS]; Lee and Peccei, 2011: 692, [7-item version]; Shore and Tetrick, 1991: 639, [17-item version]; Wayne et al., 1997: 94, [9-item version]). In this study, 9 items were eliminated from SPOS and of the remaining 17 items, 16 coincided with items that were included in the 17-item version of SPOS that Eisenberger et al. (1986: 502) recommended as a shorter version of the scale.

In Study II, the test-retest reliability of the 16 -item version of SPOS was examined. Item difficulties remained stable across the two administrations of the scale. For both administrations of SPOS high internal consistency reliabilities were obtained. The strong positive linear relation between the total scores of the two administrations of SPOS provided evidence of high test- 
retest reliability.

It is argued that validity may be a better criterion than reliability in determining the optimal number of scale points and the appropriate type of scale labeling, and it is suggested that scale design studies provide more remarkable results if both reliability and validity are considered (Chang, 1994: 206). One weakness of the present study lies in the recruitment of a small number of participants $(n=276)$. Since sample sizes were not big enough (there were approximately 70 participants in each group) for each of the four randomly distributed forms of SPOS, CFA could not be performed to compare the four different scale designs. Only, EFA was conducted by splitting the entire dataset in terms of the number of response categories (5-point Likert scale and 6-point Likert scale) and in terms of labeling anchors (fully-labeled and end-anchored) separately, to investigate the factor structure underlying SPOS items. This rendered Study I insufficient in terms of evaluating the impact of scale design on construct validity. Findings can be improved in future studies using larger samples and performing Structural Equation Modeling (SEM) methods to test the invariance of total score means, item-total correlations, and factor structure across different scale designs.

Certain limitations regarding the sample used in this study should also be acknowledged. Here, the participants consisted of only faculty members and administrative staff of different universities in Turkey to whom items related to job insecurity, such as "If the organization could hire someone to replace me at a lower salary it would do so" and "If the organization found a more efficient way to get my job done they would replace me" are not applicable since in public sector, in Turkey, employee lay-off and replacement are extremely rare. Administration of these items to employees from private sector firms with relatively higher job insecurity would be more appropriate and meaningful. Studies that will be conducted on these employees where all items can be administered would provide information on the quality of items discarded from the item pool used in the present study.

Social, behavioral, and organizational scientists use multiple-item scales as a means to assess the phenomena that they are eager to investigate, since many of the phenomena or constructs are abstract concepts which cannot be observed directly. They must rely on measurements provided by the scales that are proxies for variables under investigation. Often, researchers are not as much interested in scales per se as they are interested in the constructs and their relationships with other constructs. However, it should be recognized that haphazard measurement of constructs could yield inaccurate data which would accordingly flaw the conclusions made based on them (DeVellis, 2003: 12-14). In this study, SPOS has undergone an extensive reliability assessment and validation procedures which would provide investigators, who are interested in conducting a study on SPOS, with valuable information on the adequacy and usefulness of the scale. 


\section{REFERENCES}

Adelson, J. L. and McCoach, D. B. (2010). "Measuring the Mathematical Attitudes of Elementary Students: The Effects of a 4-Point or 5-Point Likert-Type Scale", Educational and Psychological Measurement, 70/5, 796-807.

Allen, M. J. and Yen, W. M. (2002). Introduction to Measurement Theory, 2. Edition, Waveland Press, Long Grove, Illinois.

Anastasi, A. and Urbina S. (1997). Psychological Testing, 7. Edition, Prentice-Hall: Upper Saddle River, New Jersey.

Andrews, M. C. and Kacmar, K. M. (2001). "Discriminating among Organizational Politics, Justice, and Support", Journal of Organizational Behavior, 22, 347-366.

Aselage, J. and Eisenberger, R. (2003). "Perceived Organizational Support and Psychological Contracts: A Theoretical Integration", Journal of Organizational Behavior, 24, 491-509.

Bishop, J. W., Scott, K. D., Goldsby, M. G. and Cropanzano, R. (2005). "A Construct Validity Study of Commitment and Perceived Support Variables: A Multifoci Approach across Different Team Environments", Group \& Organization Management, 30, 153-180.

Cattell, R. B. (1966). "The Scree Test for the Number of Factors", Multivariate Behavioral Research, 1, 245-276.

Chang L. (1994). "A Psychometric Evaluation of 4-Point and 6-Point Likert-Type Scales in Relation to Reliability and Validity", Applied Psychological Measurement, 18/3, 205-215.

Chang, L. (1997). "Dependability of Anchoring Labels of Likert-Type Scales", Educational and Psychological Measurement, 57/5, 800-807.

Colman, A. M., Norris, C. E. and Preston, C. C. (1997). "Comparing Rating Scales of Different Lengths: Equivalence of Scores from 5-Point and 7-Point Scales", Psychological Reports, 80, 355-362.

DeVellis, R. F. (2003). Scale Development: Theory and Applications, Second Edition, Sage Publications, Thousand Oaks, CA.

Eisenberger, R., Hungtington, R., Hutchison, S. and Sowa, D. (1986). "Perceived Organizational Support", Journal of Applied Psychology, 71, 500-507.

Fabrigar, L. R., MacCallum, R. C., Wegener, D. T. and Strahan R. (1999). "Evaluating the Use of Exploratory Factor Analysis in Psychological Research", Psychological Methods, 4/3, 272299.

Furr, M. R. and Bacharach, V. R. (2008). Psychometrics: An Introduction, Sage Publications, Thousand Oaks, California.

Furr, M. R. (2011). Scale Construction and Psychometrics for Social and Personality Psychology, Sage Publications, London.

Horn, J. L. (1965). "A Rationale and Test for the Number of Factors in Factor Analysis". Psychometrika, 30, 179-185.

IBM SPSS Statistics V23.0 Documentation. (2014). KMO and Bartlett's Test. Retrieved March 14, 2016, from https://www.ibm.com/support/knowledgecenter/SSLVMB_23.0.0/spss/ tutorials/fac_telco_kmo_01.html.

Kaiser, H.F. (1960). "The Application of Electronic Computers to Factor Analysis", Educational and Psychological Measurement, 20, 141-151.

Kurtessis, J. N., Eisenberger, R., Ford, M. T., Buffardi, L. C., Stewart, K. A. and Adis, C. S. (2015). "Perceived Organizational Support: A Meta-Analytic Evaluation of Organizational Support Theory", Journal of Management, 20/10, 1-31.

Lee, J. and Peccei, R. (2011). "Discriminant Validity and Interaction Between Perceived Organizational Support and Perceptions of Organizational Politics: A Temporal Analysis", 
Journal of Occupational and Organizational Psychology, 84/4, 686-702.

Likert, R. (1932). "A Technique for the Measurement of Attitudes", Archives of Psychology, 22/140, 1-55.

Matell M. S. and Jacoby, J. (1971). "Is There an Optimal Number of Alternatives for Likert Scale Items? Study I: Reliability and Validity", Educational and Psychological Measurement, 31, 657-674.

Mellenbergh, G. J. (2011). A Conceptual Introduction to Psychometrics: Development, Analysis, and Application of Psychological and Educational Tests, The Hague, Netherlands: Eleven International Publishing.

Murphy, K. R. and Davidshofer, C. O. (2005). Psychological Testing: Principles and Applications, 6. Edition, Pearson Education: Upper Saddle River, New Jersey.

Rhoades, L. and Eisenberger, R. (2002). "Perceived Organizational Support: A Review of the Literature", Journal of Applied Psychology, 87, 698-714.

Riggle, R. J., Edmondson, D. R. and Hansen, J. D. (2009). "A Meta-Analysis of the Relationship between Perceived Organizational Support and Job Outcomes: 20 Years of Research", Journal of Business Research, 62, 1027-1030.

Shore, L. M. and Shore, T. H. (1995). "Perceived Organizational Support and Organizational Justice", Organizational Politics, Justice, and Support: Managing Social Climate at Work, (Ed: R. Cropanzano and K. M. Kacmar), Quorum Books, Westport, CT.

Shore, L. M. and Tetrick, L. E. (1991). "A Construct Validity Study of the Survey of Perceived Organizational Support", Journal of Applied Psychology, 76/5, 637-643.

Streiner, D. L. and Norman, G. R. (2008). Health Measurement Scales: A Practical Guide to Their Development and Use, 4. Edition, Oxford University Press, New York.

Wakita, T., Ueshima, N. and Noguchi H. (2012). "Psychological Distance Between Categories in the Likert Scale: Comparing Different Numbers of Options", Educational and Psychological Measurement, 72/4, 533-546.

Wayne, S. J., Shore, L. M. and Liden R. C. (1997). "Perceived Organizational Support and Leader-Member Exchange: A Social Exchange Perspective", Academy of Management Journal, 40, 82-111 


\section{APPENDIX A}

\begin{tabular}{|c|}
\hline 28-ITEM VERSION OF SPOS (IN TURKISH) - STUDY I \\
\hline 1. Çalıştığım kurum, kurumun başarısı için olan katkılarıma değer verir. \\
\hline 2. Gösterdiğim fazladan çabaların bu kurumda hiçbir kıymeti yoktur. \\
\hline 3. Çalıştığım kurum benim hedeflerimi ve değerlerimi fazlasıyla dikkate alır. \\
\hline $\begin{array}{l}\text { 4. Bir sağlık problemi nedeniyle uzun süreli bir devamsızlığım olsaydı, çalıştığım kurum bunu } \\
\text { anlayışla karşılardı. }\end{array}$ \\
\hline 5. Çalıştığım kurum şikâyetlerimi ciddiye almaz. \\
\hline $\begin{array}{l}\text { 6. Çalıştığım kurum beni de etkileyebilecek bir karar alacak olsaydı, benim menfaatimi } \\
\text { önemsemezdi. }\end{array}$ \\
\hline 7. Bir problemim olduğunda çalıştığım kurum bana yardım etmek için hazırdır. \\
\hline 8. Çalıştığım kurum benim mutluluğuma gerçekten önem verir. \\
\hline $\begin{array}{l}\text { 9. Çalıştığım kurum, işimi elimden gelen en iyi şekilde yapabilmeme yardım etmek için gayret } \\
\text { sarf etmeye hazırdır. }\end{array}$ \\
\hline $\begin{array}{l}\text { 10. Kişisel bir problemimden kaynaklanan devamsızlığım olsaydı, çalıştığım kurum buna anlayış } \\
\text { göstermezdi. }\end{array}$ \\
\hline 11. Kasti olmayan bir hata yapsaydım, çalıştığım kurum bunu affederdi. \\
\hline $\begin{array}{l}\text { 12. Emekliliğime kadar burada çalışmaya devam etme kararı alacak olsam, kurumum bunu bir } \\
\text { kazanç olarak görmeyecektir. }\end{array}$ \\
\hline 13. Çalıştığım kurum bana çok az terfi imkânları sunar. \\
\hline 14. İşimi olabilecek en iyi şekilde yaptığımda bile, çalıştığım kurum bunu fark etmez. \\
\hline 15. Çalıştığım kurum iş koşullarımı değiştirmeye yönelik mantıklı bir talebimi kabul eder. \\
\hline 16. Eğer çalıştığım kurumdan bir iyilik isteseydim, bana yardım etmek için istekli olurdu. \\
\hline 17. Çalıştığım kurum, işteki memnuniyetime önem verir. \\
\hline 18. Çalıştığım kurum, fırsat olsa beni istismar eder. \\
\hline 19. Çalıştığım kurum benimle çok az ilgilenir. \\
\hline $\begin{array}{l}\text { 20. Eğer işten çıkmaya karar verecek olsaydım, çalıştığım kurum kalmam için beni ikna etmeye } \\
\text { çalışıdı. }\end{array}$ \\
\hline 21. Çalıştığım kurum fikirlerimi dikkate alır. \\
\hline 22. Çalıştığım kurum, beni işe almanın kesinlikle bir hata olduğunu düşünür. \\
\hline 23. Çalıştığım kurum işteki başarılarımla gurur duyar. \\
\hline 24. Eğer işimi zamanında bitirememiş olsaydım, çalıştığım kurum bunu anlayışla karşılardı. \\
\hline 25. Çalıştığım kurum, benim işimi, herhangi birinin de benim kadar iyi yapabileceğini düşünür. \\
\hline 26. Çalıştığım kurum bana yeteneklerime ve özelliklerime en uygun işleri vermeye çalışır. \\
\hline 27. Çalıştığım kurum, işimi benim için olabildiğince ilgi çekici hale getirmeye çalışır. \\
\hline 28. \\
\hline
\end{tabular}




\section{APPENDIX B}

\begin{tabular}{|c|c|c|c|}
\hline \multicolumn{4}{|c|}{ 16-ITEM VERSION OF SPOS (IN ENGLISH) - STUDY II } \\
\hline $\begin{array}{l}\text { Item No } \\
\text { in } \\
\text { Study II }\end{array}$ & Items & $\begin{array}{l}\text { Item No } \\
\text { in } \\
\text { Study I }\end{array}$ & $\begin{array}{l}\text { Item No in } \\
\text { Eisenberger et al.'s } \\
\text { (1986) Study }\end{array}$ \\
\hline 1 & $\begin{array}{l}\text { The organization values my contribution to its well- } \\
\text { being. }\end{array}$ & 1 & 1 \\
\hline 2 & $\begin{array}{l}\text { The organization fails to appreciate any extra effort } \\
\text { from me.* }\end{array}$ & 2 & 3 \\
\hline 3 & $\begin{array}{l}\text { The organization strongly considers my goals and } \\
\text { values. }\end{array}$ & 3 & 4 \\
\hline 4 & $\begin{array}{l}\text { The organization would ignore any complaint from } \\
\text { me.* }\end{array}$ & 5 & 6 \\
\hline 5 & $\begin{array}{l}\text { The organization disregards my best interests when it } \\
\text { makes decisions that affect me.* }\end{array}$ & 6 & 7 \\
\hline 6 & $\begin{array}{l}\text { Help is available from the organization when I have a } \\
\text { problem. }\end{array}$ & 7 & 8 \\
\hline 7 & The organization really cares about my well-being. & 8 & 9 \\
\hline 8 & $\begin{array}{l}\text { The organization is willing to extend itself in order to } \\
\text { help me perform my job to the best of my ability. }\end{array}$ & 9 & 10 \\
\hline 9 & $\begin{array}{l}\text { Even if I did the best job possible, the organization } \\
\text { would fail to notice.* }\end{array}$ & 14 & 17 \\
\hline 10 & $\begin{array}{l}\text { The organization is willing to help me when I need a } \\
\text { special favor. }\end{array}$ & 16 & 20 \\
\hline 11 & $\begin{array}{l}\text { The organization cares about my general satisfaction } \\
\text { at work. }\end{array}$ & 17 & 21 \\
\hline 12 & $\begin{array}{l}\text { If given the opportunity, the organization would take } \\
\text { advantage of me.* }\end{array}$ & 18 & 22 \\
\hline 13 & The organization shows very little concern for me.* & 19 & 23 \\
\hline 14 & The organization cares about my opinions. & 21 & 25 \\
\hline 15 & $\begin{array}{l}\text { The organization takes pride in my accomplishments } \\
\text { at work. }\end{array}$ & 23 & 27 \\
\hline 16 & $\begin{array}{l}\text { The organization tries to make my job as interesting } \\
\text { as possible. }\end{array}$ & 27 & 35 \\
\hline
\end{tabular}

